Proc. Estonian Acad. Sci. Biol. Ecol., 2001, 50, 3, 158-168

\title{
INVESTIGATIONS ON THE BALTIC SEA CONDUCTED BY THE DEPARTMENT OF MARINE BIOLOGY, INSTITUTE OF ZOOLOGY AND BOTANY (TARTU, ESTONIA), 1975-90
}

\author{
Kai PIIRSOO*, Arvi JÄRVEKÜLG, Valli PORGASAAR, Tiiu TREI, \\ Malle VIIK, and Sirje VILBASTE
}

Institute of Zoology and Botany, Estonian Agricultural University, Riia 181, 51014 Tartu, Estonia

Received 28 March 2001

\begin{abstract}
A brief review is given of the investigations conducted by the former Department of Marine Biology of the Institute of Zoology and Botany of the Academy of Sciences of the Estonian SSR, Tartu, Estonia. Major research projects and their results are presented, and the papers published on the materials collected in 1975-90 are listed.
\end{abstract}

Key words: Baltic Sea, Estonian coastal waters, hydrobiological investigations.

On 16 July 1974, a department of marine biology was founded at the Institute of Zoology and Botany of the Academy of Sciences of the Estonian SSR. The aim of its establishment was to concentrate efforts on the hydrobiological studies of the Baltic Sea, especially of the Estonian coastal waters. Although a large amount of data had been published by that time on the macrophytobenthos, macrozoobenthos, zooplankton, and fishes of the Estonian coastal waters, several research topics (bacterio- and phytoplankton, microphytobenthos, and primary production) were still poorly studied.

Hence there was an urgent need to develop comprehensive hydrobiological investigations besides fishery and ecological-sanitary research. The head and supervisor of the relevant scientific projects was A. Järvekülg. Investigations were made into water chemistry (V. Porgasaar, M. Viik) and various components of the biota: bottom invertebrates (A. Järvekülg, A. Seire, I. Lissenko, I. Tõlp), microphytobenthos (S. Vilbaste), macrophytes (T. Trei), phytoplankton and

\footnotetext{
*Corresponding author: Kai.Piirsoo@zbi.ee
} 
primary production (K. Piirsoo, V. Porgasaar, A. Randveer, K. Vilbaste), and zooplankton (K. Remm).

Among the numerous research projects carried out by the Department of Marine Biology during the period 1975-90, the following three deserve to be singled out:

1. Influence of pollution and anthropogenic eutrophication on environmental conditions and biological productivity in the coastal waters of the north-eastern part of the Baltic Sea, 1975-79.

In the first year the working group consisted only of researchers of zoobenthos and phytoplankton. Therefore, the period of 1976-79 when studies of macrophytes, zooplankton, and primary production were included in complex hydrobiological investigations was especially important. Seasonal investigations were carried out in the bays of Tallinn and Haapsalu, summer expeditions took place in the bays of Narva, Muuga, Kolga, Matsalu, Pärnu, and Kuressaare as well as in the vicinity of Vilsandi Island. According to our data, an increase occurred in the nutrient content, as well as in the species richness and biomass of phyto- and zooplankton, micro- and macrophytobenthos, and macrozoobenthos in weakly or moderately polluted coastal waters of Estonia. In strongly polluted areas a decrease was recorded in the quantitative variables of biota. In 1978 a joint Finnish-Soviet intercalibration of biological parameters was undertaken. The results, published in 1980, were used by the Soviet-Finnish working group for elaborating a scientific basis for preventing pollution in the Gulf of Finland. In 1975 A. Järvekülg promoted his D.Sc. thesis (Ecology of zoobenthos distribution in the eastern part of the Baltic Sea). In 1979 appeared the bulky monograph Macrozoobenthos in the Eastern Part of the Baltic Sea, which presented the ecological and zoogeographical characterization, and data on the dominant species, population density, and biomass, and elaborated a system of saprobic indicators for the benthal.

2. Impact of natural and anthropogenic factors on the distribution, productivity, and succession of communities in the coastal waters of Estonia, 1981-85.

Seasonal complex investigations were conducted in Matsalu Bay and summer expeditions continued in different bays of the Estonian coastal waters. From 1982, members of the department took part in 15 expeditions to the Gulf of Finland, the open Baltic, and the Skagerrak on board the research vessels AjuDag and Arnold Veimer. Two volumes of Hydrobiological Researches were edited by scientists of the department. One (1984) was devoted to the investigation of hydrochemical conditions and different components of biota in the Estonian coastal waters. The next volume (1985) focused on the application of hydrobiological data in the characterization of the ecological state of the Gulf of Finland.

3. The Baltic Project: research into the variability of the biotic components of the ecosystem of the Baltic Sea; characterization of the state of the ecosystem by bioindication method and evaluation of eutrophication related trends, 1986-90. 
Spatio-temporal changes in the distribution of the content of nutrients, chlorophyll $a$, phytoplankton, and zoobenthos were studied in the Baltic Proper, the Gulf of Finland, and the Estonian coastal waters. Long-term changes of macrozoobenthos and macrophytobenthos were observed in Matsalu Bay. The bioindicators of macrozoobenthos and macrophytobenthos were elaborated for the benthal. Methods were developed for the estimation of water trophy on the basis of zooplankton and chlorophyll parameters. A monograph on the composition and dynamics of zooplankton in Matsalu Bay was published by K. Remm in 1986, and two popular scientific books dealing with the plants on the bottom of the Baltic Sea and the phytobenthos of Matsalu Bay were published by T. Trei in 1991. The researchers of the department took part in the international patchiness experiment PEX-86, carried out in the eastern Gotland Basin. The international experiment SKAGEX-90 was performed in the Skagerrak in 1990, and the results of the experiment were published in 1999.

Since the end of the 1980s, the department, restructured later into a group of river biology at the Institute of Zoology and Botany, has been engaged in complex investigations of the Estonian rivers, streams, and ditches.

A large number of macrozoobenthos samples, diatom slides, and a voluminous herbarium of bottom plants were collected in 1975-90. Some original data on hydrological and hydrochemical variables as well as on the chlorophyll content and phytoplankton and zooplankton biomass of the Estonian coastal waters and of the Baltic Proper are available in databases. Two Ph.D. theses, one in macrozoobenthos (A. Seire) and the other in zooplankton (K. Remm), and four M.Sc. theses, in microphytobenthos (S. Vilbaste), phytoplankton (K. Piirsoo and A. Randveer), and water chemistry (M. Viik), were completed at the department. Numerous papers were published on the material collected during the period 1975-90 (see Appendix for a list).

\section{ACKNOWLEDGEMENT}

We would like to thank Ester Jaigma for linguistic help.

APPENDIX

\section{PAPERS PUBLISHED ON THE MATERIAL COLLECTED DURING THE PERIOD 1975-90}

Andersin, A.-B., Järvekülg, A., Lassig, J., Sandler, H., Seire, A. \& Varmo, R. 1980. Finnish-Soviet intercalibration of biological parameters used for monitoring the conditions of the Gulf of Finland. 6. Macrozoobenthos. Meri, 8, 31-51.

Barinova, S. P., Forsskåhl, M., Kukk, E., Melnikova, T., Melvasalo, T., Niemi, Å., Piirsoo, K. \& Viljamaa, H. 1980. Finnish-Soviet intercalibration of biological parameters used for the Gulf of Finland. 4. Phytoplankton. Meri, 8, 11-24. 
Carell, B., Dunca, E., Gärdenfors, U., Kulakowski, E., Lindh, U., Mutvei, H., Nyström, J., Seire, A., Selpukhina, T., Timm, H., Westermark, T. \& Zingenow, W. 1995. Biomonitoring of pollutants in a history perspective: Emphasis on mussel and snail shell methodology. Ann. Chim. Soc. Chim. Italiana, 85, 353-370.

Davidan, I., Belyaev, M., Jankovski, H., Järvekülg, A., Lääne, A., Savchuk, O. \& Yurkowskis, A. 1986. National project Baltic. The main results of studies. In Baltic Sea Monitor. Symp., Baltic Sea Environ. Proc., Helsinki, 19, 341-349.

Dunca, E., Mutvei, H. \& Seire, A. 1996. Deformation and structural modifications of Macoma (Bivalvia, Mollusca) shells caused by industrial pollution in Tallinn Bay, Estonia. Bull. Inst. Oceanogr. Monaco, No Special, 14, 4, 91-96.

Järvekülg, A. 1976. Zoobenthos as an indicator of the pollution, eutrophication and self-purification of the benthal of the Baltic Sea. Ambio, Special Report, 4, 81-88.

Järvekülg, A. 1977. Problems of eutrophication: the Baltic Sea. In Anthropogenic Eutrophication of the Natural Waters, Vol. I, pp. 51-55. Acad. Sci. USSR, Chernogolovka (in Russian).

Järvekülg, A. 1978. Matsalu lahe eutrofeerumisest, selle mõjust põhjaloomastikule ja eutrofeerumise pidurdamise võimalustest. In Matsalu märgala - uue kategooriaga looduskaitseobjekt Eesti NSV-s, pp. 48-51. Eesti NSV Metsamajanduse ja Looduskaitse Ministeerium. Matsalu Riiklik Looduskaitseala, Tallinn.

Järvekülg, A. 1978. State and perspectives of marine ecological investigations in the Estonian SSR. In Problems of Contemporary Ecology. Abstracts of the Republican Conference (Frey, T., ed.), pp. 102-104. Acad. Sci. Estonian SSR, Tartu (in Russian).

Järvekülg, A. 1979. Bottom Fauna of the Eastern Part of the Baltic Sea. Composition and Ecology of the Distribution. Valgus, Tallinn (in Russian).

Järvekülg, A. 1979. Eutrophication problems in the seas. Vodnye resursy, 4, 31-42 (in Russian).

Järvekülg, A. 1979. Ecology of bivalve molluscs in the eastern part of the Baltic Sea. In Molluscs, the Main Results in Their Investigations (Likharev, I., ed.), pp. 45-47. Nauka, Leningrad (in Russian).

Järvekülg, A. 1979. Characteristics of the zoobenthos in the eastern part of the Baltic Proper. In Fisheries Investigations in the Basin of the Baltic Sea, 5, pp. 16-42. Zvajgzne, Riga (in Russian).

Järvekülg, A. 1982. Läänemere antropogeenne eutrofeerumine. In Eesti NSV rannikumere kaitse (Järvekülg, A., ed.), pp. 15-27. Valgus, Tallinn.

Järvekülg, A. 1982. Läänemere saastumise bioindikaatorid. In Eesti NSV rannikumere kaitse (Järvekülg, A., ed.), pp. 74-80. Valgus, Tallinn.

Järvekülg, A. 1982. Muutustest Matsalu lahe põhjaloomastikus aastail 1962-1975 seoses eutrofeerumisega ja soolsuse suurenemisega. In Eesti NSV Riiklike Looduskaitsealade Teaduslikud Tööd, Vol. III (Paakspuu, V., ed.), pp. 43-52. Valgus, Tallinn.

Järvekülg, A. 1982. Changes of the zoobenthos in the deep Baltic Sea and in the coastal waters of Estonia under human activity. In Problems of Contemporary Ecology. Abstracts of the Republican II Conference in Ecology (Frey, T., ed.), pp. 105-106. Acad. Sci. Estonian SSR, Tartu (in Russian).

Järvekülg, A. 1983. Biogeographical analysis of the bottom fauna in the Baltic Sea. Biol. morya, 4, 3-9 (in Russian).

Järvekülg, A. 1983. Zoobenthos. In Ecosystem and its Components. Project Baltica. Problems Concerning the Study and Mathematical Modeling of the Ecosystems in the Baltic Sea, Vol. I (Davidan, I. N., Savchuk, O. P. \& Sustanov, J. E., eds.), pp. 184-191. Gidrometeoizdat, Leningrad (in Russian).

Järvekülg, A. 1984. Matsalu lahe põhjaloomastik aastail 1977-1981. In Loodusvaatlusi 1981, Vol. I (Mägi, E., comp.), pp. 121-127. Valgus, Tallinn.

Järvekülg, A. 1984. Zoobenthos in the central and eastern part of the Baltic Sea. In Review of the Biological Productivity in the Baltic Sea, Vol. 3, pp. 155-256. SEV, Moscow (in Russian).

Järvekülg, A. 1985. Matsalu lahe põhjaloomastik. In Matsalu - rahvusvahelise tähtsusega märgala (Kumari, E., comp.), pp. 53-76. Valgus, Tallinn. 
Järvekülg, A. 1985. Anthropogenic eutrophication of the seas. In Anthropogenic Eutrophication of the Natural Waters, pp. 234-245. Acad. Sci. SSSR, Chernogolovka (in Russian).

Järvekülg, A. 1989. Problems of the eutrophication. In Main Tendencies in Evolution of Ecosystems. Project Baltica. Problems Concerning the Study and Mathematical Modeling of the Ecosystems in the Baltic Sea, Vol. IV (Davidan, I. N. \& Savchuk, O. P., eds.), pp. 61-67. Gidrometeoizdat, Leningrad (in Russian).

Järvekülg, A. 1997. Changes in the biota of the Baltic Sea and their causes. In The Baltic Sea and its Environment. ESTO-96 Twin Symposium, pp. 47-52. Estonian Acad. Publishers, Tallinn.

Järvekülg, A. 1997. Uustulnukad Läänemere selgrootute faunas. In Problems of Contemporary Ecology. Short Communications of Estonian VII Conference in Ecology (Frey, T. ed.), pp. 56-59. IM Saare, Tartu.

Järvekülg, A. \& Kukk, E. 1983. General problems of the bioindication in the Gulf of Finland. In Universal Indicators for Water Quality - 83. Practical Problems of Biotesting and Bioindication (Buyanovskaya, A. A., ed.), pp. 136-143. Acad. Sci. SSSR, Chernogolovka (in Russian).

Järvekülg, A. \& Kukk, E. 1985. General problems of the bioindication of the condition of the Gulf of Finland. In Problems Concerning Bioindication of the Ecological Condition of the Gulf of Finland. Hydrobiological Researches, Vol. XV (Trei, T. ed.), pp. 7-12. Valgus, Tallinn.

Järvekülg, A., Kukk, E., Lassig, J., Melvasalo, T., Niemi, Å. \& Saava, A. 1980. Finnish-Soviet intercalibration of biological parameters used for monitoring the conditions of the Gulf of Finland. 1. General information. 2. Resume of results. 3. Recommendations. Meri, 8, 4-10.

Järvekülg, A., Kukk, E., Saava, A., Kangas, P., Lassig, J. \& Niemi, Å. 1987. The ecological condition of the Gulf of Finland: Microbiological and phytoplanktonic intercalibrations and review of macrophyte investigations. Introduction and summary. Meri, 13, 3-6.

Järvekülg, A. \& Ojaveer, E. 1975. A short review on activities of the PM Section of the Estonian Republican IBP Committee. In Estonian Contributions to the International Biological Programme, IV, 1974 (Frey, T., Kangur, M. \& Elberg, K., eds.), pp. 5-21. Acad. Sci. Estonian SSR, Tartu.

Järvekülg, A. \& Olenin, S. 1989. Zoobenthos. In Main Tendencies in Evolution of Ecosystems. Project Baltica. Problems Concerning the Study and Mathematical Modeling of the Ecosystems in the Baltic Sea, Vol. IV (Davidan, I. N. \& Savchuk, O. P., eds.), pp. 102-105. Gidrometeoizdat, Leningrad (in Russian).

Järvekülg, A., Piirsoo, K., Porgasaar, V., Remm, K., Seire, A. \& Vilbaste, S. 1981. Inimtegevuse mõju Haapsalu lahe vee omadustele, elustikule ja ökoloogilisele seisundile. In Inimtegevus ja keskkonnakaitse. Teaduslik-praktiline konverents (Ratas, R., ed.), pp. 73-76. Acad. Sci. Estonian SSR, Tallinn.

Järvekülg, A. \& Porgasaar, V. 1987. Matsalu laht kui eutrofeeruv veeökosüsteem. In Matsalu Riikliku Looduskaitseala ökosüsteemide dünaamika ja seisund, pp. 48-53. Valgus, Tallinn.

Järvekülg, A., Porgasaar, V. \& Remm, K. 1985. Biogeenidesisaldus Matsalu lahte voolavas vees. In Loodusvaatlusi 1983, Vol. I (Kastepõld, E., comp.), pp. 112-120. Valgus, Tallinn.

Järvekülg, A. \& Seire, A. 1984. Changes of the bottom fauna in the Bay of Tallinn in the period of 1963-1977. In Biological Regime of the Baltic Sea. Hydrobiological Researches, Vol. XII (Järvekülg, A. comp.), pp. 102-115. Acad. Sci. Estonian SSR, Tallinn (in Russian).

Järvekülg, A. \& Seire, A. 1985. Long-term changes in the bottom fauna of Tallinn Bay and their causes. In Problems Concerning Bioindication of the Ecological Condition of the Gulf of Finland. Hydrobiological Researches, Vol. XV (Trei, T. ed.), pp. 148-154. Valgus, Tallinn.

Järvekülg, A. \& Seire, A. 1994. Bottom fauna of the Strait of Väike Väin in 1993. In Ecological Studies in the Aquatic Environment of Väike Väin Strait in West Estonia (Woitsch, E., ed.), pp. 54-61. Yliopistopaino, Helsinki.

Järvekülg, A., Trei, T., Porgasaar, V. \& Piirsoo, K. 1978. Influence of human activities on the biological regime of the Baltic Sea. In Problems of Contemporary Ecology. Abstracts of the Republican Conference (Frey, T., ed.), pp. 114-115. Acad. Sci. Estonian SSR, Tartu (in Russian). 
Järvekülg, A., Trei, T. \& Vilbaste, S. 1985. Bentos Läänemere põhja ökoloogilise seisundi näitajana. In Problems of Contemporary Ecology. Abstracts of the Republican III Conference in Ecology (Frey, T., ed.), pp. 78-80. Tartu State University, Tartu.

Kahru, M., Nõmmann, S., Simm, M. \& Vilbaste, K. 1986. Plankton distribution and processes in the Baltic boundary zones. In Marine Interfaces Ecohydrodynamics (Nihoul, J. C. J., ed.), pp. 273-294. Elsevier, Amsterdam.

Kukk, H. \& Trei, T. 1982. Distribution of the bottom flora in Tallinn Bay and in the northern part of Pärnu Bay. In Problems of Contemporary Ecology. Abstracts of the Republican II Conference in Ecology (Frey, T., ed.), pp. 106-107. Acad. Sci. Estonian SSR, Tartu (in Russian).

Ojaveer, E., Erm, V., Järvekülg, A. \& Tenson, R. 1988. Pärnu lahe ökosüsteemi muutustest viimastel aastakümnetel. In Problems of Contemporary Ecology. Abstracts of the Republican IV Conference in Ecology (Frey, T., ed.), pp. 100-102. Tartu State University, Tartu.

Paakspuu, V., Vissak, P. Mägi, E., Miilmets, A. \& Järvekülg, A. 1989. Matsalu - a natural park. In Natural Parks of the Baltic Countries and Byelorussia, pp. 72-101. Mysl', Moskva (in Russian).

Piirsoo, K. 1979. On phytoplankton of West-Estonian coastal waters in summer. Proc. Acad. Sci. Estonian SSR. Biol., 28, 56-67 (in Russian).

Piirsoo, K. 1982. Saastumise mõju Eesti rannikumere fütoplanktoni liigilisele koosseisule ja biomassile. In Eesti NSV rannikumere kaitse (Järvekülg, A., ed.), pp. 49-54. Valgus, Tallinn.

Piirsoo, K. 1982. Peculiarities of the species composition, seasonal and annual dynamics of phytoplankton in the Tallinn Bay, influenced by human activity. In Problems of Contemporary Ecology. Abstracts of the Republican II Conference in Ecology (Frey, T., ed.), pp. 107-108. Acad. Sci. Estonian SSR, Tartu (in Russian).

Piirsoo, K. 1984. The phytoplankton of Haapsalu Bay and its seasonal dynamics. In Hydrological Regime of the Baltic Sea. Hydrobiological Researches, Vol. XIII (Järvekülg, A., ed.), pp. 24-33. Acad. Sci. Estonian SSR, Tallinn (in Russian).

Piirsoo, K. 1986. Species composition and seasonal dynamics of the phytoplankton in Matsalu Bay. Proc. Acad. Sci. Estonian SSR. Biol., 35, 61-71 (in Russian).

Piirsoo, K. 1991. Fütoplankton Eesti rannikumere troofsusastme näitajana. In Problems of Contemporary Ecology. Abstracts of the Estonian V Conference in Ecology (Frey, T., ed.), pp. 130-133. Estonian Acad. Sci., Tartu.

Piirsoo, K. 1993. Plates 12, 16, 24, 44, 81. In Intercalibration and Distribution of Diatoms Species in the Baltic Sea, Vol. 1 (Snoeijs, P., ed.), pp. 1-14, 118-129. Opulus Press, Uppsala.

Piirsoo, K. 1994. Plates 173, 174, 179, 180, 197, 198, 200. In Intercalibration and Distribution of Diatoms Species in the Baltic Sea, Vol. 2 (Snoeijs, P. \& Vilbaste, S., eds.), pp. 1-12, 113-125. Opulus Press, Uppsala.

Piirsoo, K. 1995. Plates 214, 233, 252, 262, 267. In Intercalibration and Distribution of Diatoms Species in the Baltic Sea, Vol. 3 (Snoeijs, P. \& Potapova, M., eds.), pp. 1-12, 113-125. Opulus Press, Uppsala.

Piirsoo, K. 1996. Plate 344. In Intercalibration and Distribution of Diatoms Species in the Baltic Sea, Vol. 4 (Snoeijs, P. \& Kasperovičiene, J., eds.), pp. 1-12, 113-125. Opulus Press, Uppsala.

Piirsoo, K. 1997. Environmental factors regulating the phytoplankton biomass in Estonian coastal waters. In Proc. 13th Baltic Marine Biologists Symp. (Andrušaitis, A., ed.), pp. 73-77. University of Latvia, Riga.

Piirsoo, K. 1997. Phytoplankton species composition in coastal waters of Estonia. In Proc. 14th Baltic Marine Biologists Symp. (Ojaveer, E., ed.), pp. 205-222. Estonian Acad. Publishers, Tallinn.

Piirsoo, K. \& Porgasaar, V. 1985. Peculiarities of the distribution, seasonal and annual dynamics of the phytoplankton and chlorophyll $a$ content in Tallinn Bay. In Problems Concerning Bioindication of the Ecological Condition of the Gulf of Finland. Hydrobiological Researches, Vol. XV (Trei, T., ed.), pp. 50-56. Valgus, Tallinn. 
Piirsoo, K. \& Porgasaar, V. 1985. Fütoplankton ja klorofüllisisaldus Matsalu lahes. In Matsalu rahvusvahelise tähtsusega märgala (Kumari, E., comp.), pp. 36-43. Valgus, Tallinn.

Piirsoo, K., Porgasaar, V. \& Viik, M. 1992. Environmental conditions, phytoplankton and chlorophyll $a$ in the Narva Bay (the southern part of the Gulf of Finland). Proc. Estonian Acad. Sci. Biol., 41, 149-161.

Piirsoo, K. \& Trei, T. 1997. Fütoplanktoni koosluse muutused Kuressaare lahes pärast linna reovete puhastusseadmete käikulaskmist. In Kaasaja ökoloogia probleemid, Eesti VII Ökoloogiakonverentsi lühiartiklid (Frey, T., ed.), pp. 173-177. IM Saare, Tartu.

Porgasaar, V. 1980. Matsalu lahe vee soolsusest 1975. ja 1977-1978. a. andmeil. In Loodusvaatlusi 1978, Vol. I (Mägi, E., comp.), pp. 151-160. Valgus, Tallinn.

Porgasaar, V. 1981. Matsalu lahe vee soolsusest 1979. aastal. In Loodusvaatlusi 1979, Vol. I (Kastepõld, E., comp.), pp. 26-31. Valgus, Tallinn.

Porgasaar, V. 1982. Hapniku-, fosfori- ja klorofüllisisaldus Eesti NSV rannikumere eutrofeerunud piirkondades. In Eesti NSV rannikumere kaitse (Järvekülg, A., ed.), pp. 40-48. Valgus, Tallinn.

Porgasaar, V. 1984. Chlorophyll $a$ content and hydrochemical conditions in Haapsalu Bay in 19761979. In Hydrological Regime of the Baltic Sea. Hydrobiological Researches, Vol. XIII (Järvekülg, A., ed.), pp. 9-23. Acad. Sci. Estonian SSR, Tallinn (in Russian).

Porgasaar, V. 1985. Matsalu lahe vee füiusikalised ja keemilised omadused ning nende seos klorofülli $a$ sisaldusega. 1. Vee füüsikalised ja keemilised omadused. Proc. Acad. Sci. Estonian SSR. Biol., 34, 119-130.

Porgasaar, V. 1985. Matsalu lahe vee füüsikalised ja keemilised omadused ning nende seos klorofülli $a$ sisaldusega. 2. Klorofüll $a$ kui vee troofsuse näitaja. Proc. Acad. Sci. Estonian SSR. Biol., 34, 197-204.

Porgasaar, V. 1993. Content and distribution of phosphorus and nitrogen in the coastal waters of West Estonia. Proc. Estonian Acad. Sci. Ecol., 3, 166-180.

Porgasaar, V. \& Remm, K. 1988. Vee klorofülli-, fosfori- ja lämmastikusisalduse vaheline sõltuvus Lääne-Eesti rannikumere vees. In Problems of Contemporary Ecology. Abstracts of the Republican IV Conference in Ecology (Frey, T., ed.), pp. 124-127. Tartu Riiklik Ülikool, Tartu.

Porgasaar, V., Remm, K. \& Viik, M. 1982. Hydrochemical and hydrobiological phenomena of eutrophication in the Matsalu Bay. In Problems of Contemporary Ecology. Abstracts of the Republican II Conference in Ecology (Frey, T., ed.), p. 112. Acad. Sci. Estonian SSR, Tartu (in Russian).

Porgasaar, V. \& Simm, H. 1985. Matsalu lahe hüdrokeemiline režiim. In Matsalu - rahvusvahelise tähtsusega märgala (Kumari, E., comp.), pp. 26-35. Valgus, Tallinn.

Porgasaar, V. \& Viik, M. 1982. Matsalu lahe vete biogeenide ja klorofüll a sisaldus. In Keskkonnakaitse, Informatsiooniseeria, Vol. XIV, No. 5, pp. 6-9. Eesti NSV Metsamajanduse ja Looduskaitse Ministeerium, Tallinn.

Porgasaar, V. \& Viik, M. 1982. Biogeenide sisaldus Matsalu lahe vees 1979...1980. In Loodusvaatlusi 1980, Vol. I (Kastepõld, E., comp.), pp. 166-177. Valgus, Tallinn.

Porgasaar, V. \& Viik, M. 1984. Biogeenide sisalduse sesoonne dünaamika Matsalu lahe vees 1981. a. vegetatsiooniperioodil. In Loodusvaatlusi 1981, Vol. I (Mägi, E., comp.), pp. 158168. Valgus, Tallinn.

Porgasaar, V., Viik, M. \& Paakspuu, V. 1990. Fosfori- ja lämmastikusisaldus Matsalu lahe valgla vooluveekogudes. In Loodusvaatlusi 1987, Vol. I (Mägi, E. ed.), pp. 51-65. Valgus, Tallinn.

Randveer, A. 1982. Seasonal dynamics of the phytoplankton in Pärnu Bay in 1979-1981. In Problems of Contemporary Ecology. Abstracts of the Republican II Conference in Ecology (Frey, T., ed.), pp. 108-109. Acad. Sci. Estonian SSR, Tartu (in Russian).

Randveer, A. 1984. On the phytoplankton of the western coastal waters of the islands Saaremaa and Hiiumaa in 1979. In Hydrological Regime of the Baltic Sea. Hydrobiological Researches, Vol. XIII (Järvekülg, A., ed.), pp. 63-73. Acad. Sci. Estonian SSR, Tallinn (in Russian). 
Randveer, A. 1988. Ava-Läänemere fütoplanktoni ruumiline ja ajaline muutlikkus. In Problems of Contemporary Ecology. Abstracts of the Republican IV Conference in Ecology (Frey, T., ed.), pp. 132-133. Tartu Riiklik Ülikool, Tartu.

Randveer, A. 1994. Suvise fütoplanktoni liigiline koosseis ja biomass Soome lahe lõunaosas 1980. aastail. Proc. Estonian Acad. Sci. Biol., 43, 45-64.

Randveer, A. \& Viik, M. 1994. The state of the phytoplankton in the eastern part of the Gulf of Finland in November 1990 and 1991. Proc. Estonian Acad. Sci. Biol., 43, 173-183.

Remm, K. 1982. Andmeid Virtsu piirkonna rannikualade ja Matsalu lahe zooplanktonist 1980. a. juulis. In Loodusvaatlusi 1980, Vol. I (Kastepõld, E., comp.), pp. 120-125. Valgus, Tallinn.

Remm, K. 1984. On the zooplankton of Haapsalu Bay. In Hydrological Regime of the Baltic Sea. Hydrobiological Researches, Vol. XIII (Järvekülg, A., ed.), pp. 34-43. Acad. Sci. Estonian SSR, Tallinn (in Russian).

Remm, K. 1985. Zooplankter Filina longiseta (Ehr.) Lääne-Eesti rannikumere eutrofeerumise näitajana. In Problems of Contemporary Ecology. Abstracts of the Republican III Conference in Ecology (Frey, T., ed.), pp. 209-210. Tartu Riiklik Ülikool, Tartu.

Remm, K. 1986. Matsalu lahe zooplanktoni koosseis ja dünaamika. Valgus, Tallinn.

Remm, K. 1987. A statistical method for the assessment of ecological relationships on the example of Filina longiseta (Ehr.) (Rotatoria). Proc. Acad. Sci. Estonian SSR. Biol., 36, 319-326.

Remm, K. 1989. A zooplankton bioindication system for the Matsalu Bay: A probabilistic approach. Proc. Acad. Sci. Estonian SSR. Biol., 38, 61-71.

Remm, K. 1990. Zooplankton as an Indicator of the Sea Eutrophication on the Example of WestEstonian Coastal Waters. Abstract of PhD Thesis. Inst. Zool. Acad. Sci. SSSR, Leningrad (in Russian).

Seire, A. 1984. On the seasonal dynamics of the bottom of Haapsalu Bay. In Hydrological Regime of the Baltic Sea. Hydrobiological Researches, Vol. XIII (Järvekülg, A., ed.), pp. 54-62. Acad. Sci. Estonian SSR, Tallinn (in Russian).

Seire, A. 1985. Põhjaloomastiku sesoonsed ja aastatevahelised muutused Haapsalu lahe $\gamma$-polü-, $\alpha$-meso- ja oligosaproobses tsoonis aastail 1976-1979. In Problems of Contemporary Ecology. Abstracts of the Republican III Conference in Ecology (Frey, T. ed.), pp. 213-215. Tartu Riiklik Ülikool, Tartu.

Seire, A. 1988. Zoobenthos in the surroundings of Vilsandi Island. In Vilsandi Island - Background Standard for Ecological Monitoring (Ratas, U. \& Nilson, E., eds.), pp. 101-106. Valgus, Tallinn (in Russian).

Seire, A. 1988. Benthic fauna in the deep areas of the Gulf of Finland and Eastern Gotland Basin in 1984 and 1985. Proc. Acad. Sci. Estonian SSR. Biol., 37, 67-73.

Seire, A. 1990. Composition, Distribution and Dynamics of Macrozoobenthos in Organically Polluted Bay of Haapsalu, Eastern Baltic. Abstract of PhD Thesis. Inst. Evol. Morphology and Ecol. Animals Acad. Sci. SSSR, Moscow (in Russian).

Seire, A. 1992. Benthic macrofauna of the deep areas of the Gulf of Finland in 1989/1990 compared with earlier investigations. In Proc. 12th Symp. Baltic Marine Biologists (Bjørnestad, E., Hagermam, L. \& Jensen, K., eds.), pp. 151-156. Olsen \& Olsen, Fredensborg.

Seire, A. 1992. Composition, distribution and dynamics of macrozoobenthos in organically polluted Bay of Haapsalu (Eastern Baltic). In Proc. 17th Conf. Baltic Oceanogr., pp. 1-15. Swedish Meteorological and Hydrological Institute, Norrköping.

Seire, A., Mutvei, H. \& Dunca, E. 1993. Growth rates and structure of Macoma baltica shells, collected on the north coast of Estonia, as environmental indicators. In Human Impact on Environment. Pilot Study in Baltic (Punning, J.-M. \& Hult, J., eds.), pp. 169-195. Institute of Ecology, Estonian Acad. Sci., Tallinn.

Seire, A., Carrell, B., Westermark, T., Mutvei, H. \& Bignert, A. 1996. Bivalve shells as environmental archives in brackish water. Elemental and radioactivity studies of Estonian Macoma baltica shells. Bull. Inst. Oceanogr. Monaco, No Special, 14, 4, 97-104. 
Simm, H., Järvekülg, A. \& Velner, H. 1982. Anthropogenic influence in the water basin of the Baltic Sea and the use of the scientific methods for the sea protection. In Problems of Preservation, Protection and Improving of the Natural Waters (Buyanovskaya, A. A., ed.), pp. 73-83. Nauka, Moscow (in Russian).

Simm, M. \& Randveer, A. 1985. Seasonal changes of the plankton biomass and species diversity in Pärnu Bay. Proc. Acad. Sci. Estonian SSR. Biol., 34, 112-118 (in Russian).

Snoeijs, P. \& Vilbaste, S. (eds.) 1994. Intercalibration and Distribution of Diatoms Species in the Baltic Sea, Vol. 2. Opulus Press, Uppsala.

Talpsepp, L., Künnis, K., Pavelson, J., Piirsoo, K., Porgasaar, V. \& Põder, T. 1999. Hydrophysical variability in the central and eastern Skagerrak during SKAGEX-90 and its reflection in biological parameters. ICES J. Marine Sci., 56, Supplement, 72-83.

Talpsepp, L., Pavelson, J., Põder, T., Künnis, K., Piirsoo, K. \& Porgasaar, V. 1999. On water masses and biological variability in the central and eastern Skagerrak during SKAGEX-90: Inflow of the Atlantic water. SKAGEX. The Skagerrak experiment (Føyn, L., ed.). Fisken og Havet, 9, 1-15.

Trei, T. 1975. Flora and vegetation in the coastal waters of western Estonia. Merentutkimuslait. Julk./ Havshorskningsinst. Skr., 239, 348-351.

Trei, T. 1976. Brown and Red Algae in the Coastal Waters of West Estonia. Zvajgzne, Riga (in Russian).

Trei, T. 1977. Green algae and charophyta in the coastal waters of West Estonia. Tr. BNIRO, 124, 27-30 (in Russian).

Trei, T. 1978. The physiognomy and structure of the sublittoral macrophyte communities in Kassari Bay (an area between the Isles of Hiiumaa and Saaremaa). Kieler Meeresforsch. Sonderheft, 4, 117-121.

Trei, T. 1978. Factors determining the distribution of plant communities in the coastal waters of Western Estonia. In Problems of Contemporary Ecology. Abstracts of the Republican Conference (Frey, T., ed.), pp. 108-109. Acad. Sci. Estonian SSR, Tartu (in Russian).

Trei, T. 1981. Saastumise toimest põhjataimestiku levikule Haapsalu lahes. In Inimtegevus ja keskkonnakaitse. Teaduslik-praktiline konverents (Ratas, R., ed.), pp. 76-78. Acad. Sci. Estonian SSR, Tallinn.

Trei, T. 1982. A Review of Hydrobotanical Investigations in the Waters of the Soviet Baltic (18031980). Acad. Sci. Estonian SSR, Tallinn (in Russian).

Trei, T. 1982. Cladophora glomerata Matsalu lahes. In Loodusvaatlusi 1980, Vol. I (Kastepõld, E., comp.), pp. 144-152. Valgus, Tallinn.

Trei, T. 1982. Inimtegevuse mõju põhjataimestiku levikule Kuressaare ja Haapsalu lahes. In Eesti NSV rannikumere kaitse (Järvekülg, A., ed.), pp. 60-67. Valgus, Tallinn.

Trei, T. 1983. The species composition of phytobenthos in some shallow bays of western Estonia. Proc. Acad. Sci. Estonian SSR. Biol., 32, 245-253 (in Russian).

Trei, T. 1984. The influence of human activity upon the bottom vegetation in some shallow bays of western Estonia. In Hydrological Regime of the Baltic Sea. Hydrobiological Researches, Vol. XIII (Järvekülg, A., ed.), pp. 74-81. Acad. Sci. Estonian SSR, Tallinn (in Russian).

Trei, T. 1984. Phytocenological characteristics of the Baltic Sea. In Review on the Biological Productivity of the Baltic Sea, Vol. 3, pp. 42-78. Moscow (in Russian).

Trei, T. 1984. Long-term changes in the bottom flora of the Haapsalu Bay. Limnologica (Berlin), 15, 351-352.

Trei, T. 1985. Long-term changes in the bottom macroflora of the coastal waters of Estonia. In Problems Concerning Bioindication of the Ecological Condition of the Gulf of Finland. Hydrobiological Researches, Vol. XV (Trei, T., ed.), pp. 117-122. Valgus, Tallinn.

Trei, T. 1985. Matsalu lahe veetaimestik. In Matsalu - rahvusvahelise tähtsusega märgala (Kumari, E., comp.), pp. 44-52. Valgus, Tallinn.

Trei, T. 1985. Phytocenological characterization of the phytobenthos in the surroundings of Kihnu Island and in Pärnu Bay. Proc. Acad. Sci. Estonian SSR. Biol., 34, 331-337 (in Russian). 
Trei, T. 1986. The floristic composition of the phytobenthos in Pärnu Bay and in the surroundings of Kihnu Island. Proc. Acad. Sci. Estonian SSR. Biol., 35, 56-60 (in Russian).

Trei, T. 1987. Phytobenthos in the waters of the Vilsandi State Nature Reserve. Proc. Acad. Sci. Estonian SSR. Biol., 36, 227-235.

Trei, T. 1987. Plant communities in Matsalu Bay in 1984. In Loodusvaatlusi 1984, Vol. I, pp. 46-59. Valgus, Tallinn.

Trei, T. 1988. Muutused Lääne-Eesti merelahtede põhjataimestikus. In Taimeriigi kaitsest Eesti NSV-s (Laasimer, L.-M., comp.), pp. 97-103. Valgus, Tallinn.

Trei, T. 1988. A survey of botanical investigations of the waters of the Soviet Baltic in the 19th century and in the first half of the 20th century. Kieler Meeresforsch., Sonderheft, 3, 50-53.

Trei, T. 1991. Taimed Läänemere põhjal. Valgus, Tallinn.

Trei, T. 1991. Matsalu lahe põhjataimestik. Matsalu Riiklik Looduskaitseala, Tallinn.

Trei, T., Kukk, H. \& Kukk, E. 1987. Phytobenthos as indicator of the degree of pollution in the Gulf of Finland and in neighboring sea areas. Meri, 13, 63-110.

Trei, T. \& Piirsoo, K. 1996. Short-term effect of the sewage treatment plant on the phytoplankton in Kuressaare Bay. Proc. Estonian Acad. Sci. Ecol., 6, 154-166.

Velner, H. \& Järvekülg, A. 1985. Eutrophication problems and protection methods of the Baltic Sea. In Anthropogenic Eutrophication of the Natural Waters, pp. 35-48. Acad. Sci. SSSR, Chernogolovka (in Russian).

Vilbaste, K. 1987. Primary productivity of a shallow inlet. Proc. Acad. Sci. Estonian SSR. Biol., 36, 244-248 (in Russian).

Vilbaste, S. 1981. Matsalu lahe epifüütsetest ränivetikatest. Loodusvaatlusi 1979, Vol. I (Kastepõld, E., comp.), pp. 32-35. Valgus, Tallinn.

Vilbaste, S. 1982. Eesti NSV rannikumere mikrofütobentos. In Eesti NSV rannikumere kaitse (Järvekülg, A., ed.), pp. 55-59. Valgus, Tallinn.

Vilbaste, S. 1982. The species composition and seasonal dynamics of the microphytobenthos of Matsalu Bay. Proc. Acad. Sci. Estonian SSR. Biol., 31, 233-243 (in Russian).

Vilbaste, S. 1982. On the ecological factors determining the distribution of microphytobenthos in the shallow bays of West-Estonia. In Problems of Contemporary Ecology. Abstracts of the Republican II Conference in Ecology (Frey, T., ed.), p. 109. Acad. Sci. Estonian SSR, Tartu (in Russian).

Vilbaste, S. 1984. On the microphytobenthos of Haapsalu Bay. In Hydrological Regime of the Baltic Sea. Hydrobiological Researches, Vol. XIII (Järvekülg, A., ed.), pp. 44-53. Acad. Sci. Estonian SSR, Tallinn (in Russian).

Vilbaste, S. 1987. The investigation of microphytobenthos of Rame Bay by the glass slide method. Proc. Acad. Sci. Estonian SSR. Biol., 36, 44-52 (in Russian).

Vilbaste, S. 1988. Ökoloogiliste tegurite osa mikrofütobentose ajalise ja ruumilise muutlikkuse kujunemisel. In Problems of Contemporary Ecology. Abstracts of the Republican IV Conference in Ecology (Frey, T., ed.), pp. 166-169. Tartu State University, Tartu.

Vilbaste, S. 1989. The importance of ecological factors in the realization of the temporal and spatial variability of the microphytobenthos in shallow Haapsalu Bay. Proc. Acad. Sci. Estonian SSR. Biol., 38, 219-231 (in Russian).

Vilbaste, S. 1990. The seasonal dynamics of microscopic benthos algae development in the shallow bays in the north-eastern part of the Baltic Sea. Botan. zh., 75, 516-521 (in Russian).

Vilbaste, S. 1991. Mikrofütobentose osa rannikumere ökosüsteemis. In Problems of Contemporary Ecology. Abstracts of the Estonian V Conference in Ecology (Frey, T., ed.), pp. 189-190. Estonian Acad. Sci., Tartu.

Vilbaste, S. 1992. Microphytobenthos - a part of the coastal ecosystem of Haapsalu Bay, the Baltic Sea. Proc. Estonian Acad. Sci. Ecol., 2, 119-126.

Vilbaste, S. 1993. Plates 17, 29, 35, 54-58, 71. In Intercalibration and Distribution of Diatoms Species in the Baltic Sea, Vol. 1 (Snoeijs, P., ed.), pp. 1-14, 118-129. Opulus Press, Uppsala. 
Vilbaste, S. 1995. Plates 247-249, 254, 258, 264, 266, 298. In Intercalibration and Distribution of Diatoms Species in the Baltic Sea, Vol. 3 (Snoeijs, P. \& Potapova, M., eds.), pp. 1-12, $113-$ 125. Opulus Press, Uppsala.

Vilbaste, S. 1995. The epiphytic and microphytobenthic diatoms in Estonian coastal waters (the Baltic Sea). In Proc. 13th Internat. Symp. Diatoms (Marino, D. \& Montresor, M., eds.), pp. 259-269. Biopress Ltd, Bristol.

Vilbaste, S. 1996. Plates 305, 307, 319, 351, 376. In Intercalibration and Distribution of Diatoms Species in the Baltic Sea, Vol. 4 (Snoeijs, P. \& Kasperovičiene, J., eds.), pp. 1-12, 113-125. Opulus Press, Uppsala.

Vilbaste, S. 1998. Plates 433, 466, 473, 486, 487. In Intercalibration and Distribution of Diatoms Species in the Baltic Sea, Vol. 5 (Snoeijs, P. \& Balashova, N., eds.), pp. 1-12, 113-125. Opulus Press, Uppsala.

Vilbaste, S. \& Leskinen, E. 1994. Species composition and biomass of epiphytic microalgae of Väike Väin, Western Estonia. In Ecological Studies in the Aquatic Environment of Väike Väin Strait in West Estonia (Woitsch, E., ed.), pp. 32-41. Yliopistopaino, Helsinki.

Vilbaste, S., Sundbäck, K., Nilsson, C. \& Truu, J. 2000. Distribution of benthic diatoms in the littoral zone of the Gulf of Riga, the Baltic Sea. Eur. J. Phycol., 35, 373-384.

\section{ZOOLOOGIA JA BOTAANIKA INSTITUUDI MEREBIOLOOGIA SEKTORI LÄÄNEMERE UURINGUD AASTATEL 1975-1990}

\section{Kai PIIRSOO, Arvi JÄRVEKÜLG, Valli PORGASAAR, Tiiu TREI, Malle VIIK ja Sirje VILBASTE}

On esitatud lühike ülevaade Zooloogia ja Botaanika Instituudi merebioloogia sektori uuringutest Läänemerel aastatel 1975-1990 ning toodud ära olulisemad uurimisteemad ja tähtsamad publikatsioonid, mis on avaldatud nendel aastatel kogutud materjalide põhjal. 